\title{
The Right of the Accused in Saudi in Criminal Procedure during Investigation Process and Arbitrary Dentation and Prohibits Torture and Protects the Rights of Suspects to Obtain Legal Council
}

\author{
Faten Mohmed Alqahtani ${ }^{1,{ }^{*}}$, Amani Ali ${ }^{1}$, Abdulrahman M.A.AlBelihi ${ }^{1}$ and Metwally Ali $^{1}$ \\ ${ }^{1}$ School of Human Development and Technocomunication (iKOM), Universiti Malaysia Perlis, Perlis, Malaysia
}

\begin{abstract}
Saudi Arabia has recent in years pass several important legislations to ensure a fair and balanced justice system, including: 1) The Law of Procedure Before Sharia Courts of September 2001, which grants defendants the right to legal representation and outlines the process by which please, evidence and experts are heard by the courts. 2) The Code of Law Practice of January 2001, which outlines requirements necessary to become an attorney and defines the duties and right of lawyers, including the right of attorneyclient privilege. 3) The Law of Criminal Procedure of May 2001, which protects a defendant right with the regard to interrogation, investigation, and incarceration; outlines a series of regulations that justice and law enforcement authorities must follow during all stages of legal process, from arrest and interrogation to trial and sentencing; prohibits torture and protects the right of suspects to obtain legal counsel; and limits the period of arbitrary detention. The main objective of this study is to examine the operation of the criminal justice system in Saudi Arabia in light of the international human rights standards pertaining to the administration of justice. It involves the international human rights treaties and focuses mainly on the instruments in which the right to a fair trail in Saudi Arabia.
\end{abstract}

\section{Background Research}

Saudi Arabia has in recent years passed several important legislations to ensure a fair and balanced justice system, including:

1. The Law of Procedure Before Sharia Courts of September 2001, which grants defendants the right to legal representation and outlines the process by which pleas, evidence and experts are heard by the courts.

2. The Code of Law Practice of January 2002, which outlines the requirements necessary to become an attorney and defined the duties and rights of lawyers, including the right of attorney-client privilege.

3. The Law of Criminal Procedure of May 2001, which protects a defendant right with regard to interrogation, investigation, and incarceration; outlines a series of regulations that justice and law enforcement authorities must follow during all stages of the legal process, from arrest and interrogation to trial and sentencing; prohibits torture and protects the rights of suspects to obtain legal counsel; and limits the period of arbitrary detention.

In 2008 the government continued its reform initiative with the allocated sum of approximately $£ 1.3$ billion for the planned reforms. The new rules, which emphasize the independence of judges, set up a Supreme Court, the main function of which is to oversee the implementation of the Sharia (Islamic Law) as well as the various laws issued by the government. The new laws also set up new specialized courts for issues relating to commerce, labour, personal status, traffic disputes, together with a fund for training old and new judges. Currently, justice in Saudi Arabia is administered by a system of Sharia courts, and judges have wide discretion to issue rulings according to their own interpretation of the Sharia texts.

* Corresponding author: bkaifi@hotmail.com 
Saudi Arabia has never promulgated a criminal code. However, a committee was appointed in 2005 to codify penal provisions but is yet to produce a draft.

\section{The Study Significance:}

The main argument in this research work may be in the following statement: 'The human rights of suspect during the fair trial procedure have many issues in the Saudi Arabian legal system and is partly compliant with international human rights standard. In order to evaluate the compatibility between the Saudi Arabia fair trial and the International human rights standard, this study examines and evaluates the mechanism of the of the pretrial and in-trial process within the Saudi Arabian legal systems and compares it with international human right standards, this study examines and evaluates the mechanism of the pre-trial and in-trial processes within the Saudi Arabian legal system and compares it with international human right standards found in international treaties. United Nations, Office of the High Commissioner for Human Rights, Status of Ratifications accessed 15 January 2013

In pursuit of these research, the study attempts to answer the following questions:

1. In Saudi Arabian is the domestic Law of Criminal Procedure consistent with Saudi Arabia's international human rights obligations with respects to the right to a fair trial and real according to Islamic law?

2. Do Saudi Arabia judicial apply the international human right standards without violating Islamic law?

3. What is the difference the system between international human right and Islamic law?

\subsection{Significant of the study}

The importance of this study lies in its timing. As stated earlier, the Saudi legal system is currently undergoing substantial changes both structurally and procedurally. The government's reform initiative takes place in the context of its desire to better achieve the objectives contained in the Sharia. Human Rights Watch conducted research missions to Saudi Arabia in November and December 2006, and again in May 2007. We found pervasive injustices in the Saudi criminal justice system and systematic and multiple violations of defendants right. Individuals in Saudi Arabia may find themselves detained and arrested for behavior that is not inherently criminal, or for apparently (and unwittingly) offending vague legal prohibitions. They may then find themselves in solitary confinement and subject to form of illtreatment. The authorities often do not inform individuals of the crime of which they are accused, or the evidence supporting the accusation. An accused person typically does not have access to a lawyer, faces abuse when refusing to incriminate him or herself, and waits excessive periods of time before trial, where he or she is often to examine witness or evidence and present a legal defense, not least because of a presumption of guilt and shifting charges. Ministry of Justice Saudi Arabia, 'History of justice in Saudi Arabia' accessed 15 September 2012

\section{Methodology}

Comparative methods are applied, as the protection of fair trial under Saudi Arabian domestic law is compared to the international human rights standards. The research examines two group of case related to the right to a fair trial: first, the domestic case, that is to say those which have been provided by Saudi Arabian authority in the Ministry of Justice.

With the exception of three group interviews with detainees in al-Ha'ir Correctional Facility and one interview with intellectuals in Riyadh, we conducted all interviews privately and individually. During the group interviews with prisoners in al-Ha'ir Correctional Facility, we asked about their individual criminal cases, cases of abuse and cases of death in custody known to them, and their individual experiences during interrogation and trial. We cross-checked allegation across these groups and with former detained account for consistency.

\section{Finding}

\subsection{Statutory law and Islamic law}

The division of respective of influence between the absolute rulers of the House of Sa'ud and the Wahhabi religious establishment has endure through subsequent centuries and periods of temporary demise of the Saudi state. The religious establishment in Saudi Arabian has board influence over everyday life. Its scholars and officials write and vet textbooks used in schools. Officials in the Commission to Promote Virtue and Prevent Vice(CPVPV) lecture at social gatherings, teach the Quran in prisons and social institutions, and keep a watchful eye over the moral behavior of the general public. Religious officials preach in local mosques where prayers attendance in mandatory. The judiciary, too, is almost the exclusive province of the religious establishment. 'King Abdul-Aziz institution announcement' (Al Riyadh newspaper 26 May 2008) 14581 accessed 29 August 2012

The Saudi government does not publish an official interpretation of Sharia. In the area of criminal law, the government has not published an interpretative text carrying the force of law of the precise definitions of acts that constitute offenses, such as "disobeying the ruler". Unlike Qatar, which also follows the Hanbali School, Saudi Arabia has no written penal code.

"The Courts shall apply rules of the Islamic Sharia in cases that are brought before them, according to the Holy Quran and the Sunna." Sharia, however, is silent on many areas in which modern life requires the application of precise legal norm. To fill this void, Saudi Arabia's prime minister (a post held currently by the king), may 
issue positive, or stator, law-called regulations to differentiate them from God-given laws of Sharia-as long as they do not conflict with Sharia precepts. Article 48 of the Basic Law, itself one such statutory law, also obliges the courts to apply Sharia rules "according to laws which are decreed by the rules in the agreement with the Holy Quran and the Sunna." Saudi Arabia has published hundreds of such statutory laws to regulate areas where Sharia precedents or interpretations have little bearing, such as traffic and banking laws.

Sheikh Mohammad Al Abdullah, the kingdom's chief prosecutor, told Human Right Watch that "all of our work follows the criminal procedure code all in cases." Most of those interviewed told Human Right Watch that the Saudi government implemented the criminal laws unevenly, and sometimes not at all. Defendants described numerous and specific instances in which prosecutors, arresting officers, and judges did not act in conformity with the law's provisions. Jeddahbased lawyers Aiman told Human Right Watch, "The criminal procedure code is still new for prison officials. A detainee has no insists on his right and know them. Nobody will tell him his rights or facilities, access to them." Hisham, a Dammam-based lawyer with trial experience, confirmed to Human Right Watch that "Judges are not very conversant in the criminal procedure code." Al-Sulami, 'Terror Cell Plotted to Kill Top Officials' Arab News accessed 18 January 2013

\subsection{Codification of criminal laws}

Saudi Arabia does not have a written penal code, but relies on judge's interpretation of the Sharia for determination of which actions constitute crimes and what the attendant punishment should be. The definitions of crimes and severity of punishment may vary far from case to case. In 2005, as Saudi Arabia was negotiating its accession to the World Trade Organization, Saudi officials revived an idea first touted by King Abd al-Aziz in the 1930s, to provide citizen, law enforcement officials, and judges with a clear, written formulation of what constitutes a crime. According to Sheikh Abd-alMukhsin al-Ubaikan, the Justice Ministry's judicial adviser and member of the Saudi Shura Council, the country's "highest leadership" approved a plan to compile Islamic jurisprudence (fiqh) in the form of articles of law "to be used by the courts but without being compulsory."

\section{Conclusion}

The kingdom of Saudi Arabia has sought to address a number of elements inherent within and outcomes associated with human rights decisions and the right to a fair trial. Nevertheless, such involvement has increase dramatically following the domestic reform implemented across Saudi Arabia. However, during the past twenty years, a remarkable shift has been witness within Saudi Arabia domestic law, which reflects positively on the human rights of suspects, initiated at the point at which constitutional reform was adopted through the
Consultative Council, and spanning up until the establishment of two human rights entities, the NSHR and the HRC.

The establishment of the LCP was one the practical implementations of the right to a fair trial, after its provision in the BLG. However, these remain notable challenges in relation to the compatibility of Saudi domestic law with international human rights standards.

But still have a long way to go because so many cases couldn't find justice, that's because there are no sentencing guidelines, including on the meaning of guilt proven beyond reasonable doubt for discretionary sentences. There is no guidelines for introducing evidence, including guidelines for assessing the credibility of witness. Ensure that witness for the prosecution and defense actually appear in court so defendants may cross-examine them and review of the decision to charge a suspect and to remind him or her in custody.

\section{References}

1. A. Abdul-Wahhab, "Human rights in qasas crimes between Sharia and international law" (PhD Thesis, Naif Arab University for Security Sciences 2000)

2. Abu Zahrah, Crime and punishment in Islamic jurisprudence (Dar alFikr Al-Arabi 1984)

3. A. Al-Barrak, "The Right of Accused to defend himself in the Saudi Criminal Justice System (Naif Arab University 2000)

4. S. Alghozy, 'The legal status of lawyer in Saudi law' (PhD Thesis, Naif Arab University 2008)

5. N. Al-Joufan, "Public hearing in the judicial domain" (2009) 5 Al-Adl 10

6. Allahim, Abdulkarim, Ta'aeweed a'n an sejn (2002) 12 Al-Adl Journal 1422

7. H. Al-Marsafawi, The fundamental of criminal procedure (Dar Al-Marifah, Egypt, Egypt, 1998) 187

8. H. Al-Qahtani, The Specialisation of thr Provinces Between Practice and Criminal Procedure Code in Saudi Arabia (PhD Thesis, Naif Arab University 2007)

9. F. Al-Shihri, "The High Administrative Court in the Board of Grievances" (Phd Thesis Arab University, Saudi Arabia 2009)

10. H. Al-Subaie, "Crime Control officer to perform some of Investigation acts under Saudi Criminal Procedure Act; Analytical and comparative study" (Master Dissertation, Naif Arab University for Security Sciences, 2006)

11. A. Al-Washmi, Fitnat Al-qul be Taleem Al Banaat (Arabic Education Center,Morocco, 2009)

12. K. Badaywe, Ijraat Raf'a Al-Dawa Fi N izam AlMurafaa Al-Sharia, (Qibba, Cairo 2006)

13. B. Hassuna, The evidence in Hudud crime in Sharia and Law (PhD Thesis, Naif Arab University Saudi Arabia 2002) 
14. Ibn Qudamah, Al Mugni, 429/7, and Jawahir AlIkleel, Imam Malik (Dar ihiya alturath Al-Arabi, 1985)

15. Ibn Taymiya, Al-Syasa al-Shar'iya, (ed Al-Afaq Al-Jadidah, Beirut 1983)

16. Ishak, 'Mabda al bad fe alkada al shari (2002) 8 AlAdl Journal

17. Y. Kilzi, Human right in the face of the authority of law enforcement officer (Naif Arab University for Security Sciences 2007)

18. Mohammad al-Ramli, Nihayat al Muhtaj fe Sharh al minhag $5 / 71$

19. A. Shalabe, Falsafat al-tshre al islami (Dar al Nahdah al-Masria 1998)

20. A. Waleed, The Independences of the commission of investigation and public prosecution in Saudi Arabia (Master Thesis, Naif Arab University 2007) 